\title{
Climate-scale hydrographic features related to foraging success in a capital breeder, the northern elephant seal Mirounga angustirostris
}

\author{
Samantha E. Simmons ${ }^{1, *}$, Daniel E. Crocker ${ }^{2}$, Jason L. Hassrick ${ }^{1}$, Carey E. Kuhn ${ }^{3}$, \\ Patrick W. Robinson ${ }^{1}$, Yann Tremblay ${ }^{4}$, Daniel P. Costa ${ }^{1}$ \\ ${ }^{1}$ Department of Ecology and Evolutionary Biology, University of California Santa Cruz, Center for Ocean Health, \\ 100 Shaffer Road, Santa Cruz, California 95060-5730, USA \\ ${ }^{2}$ Department of Biology, Sonoma State University, Rohnert Park, California 94928, USA \\ ${ }^{3}$ National Marine Mammal Laboratory, Alaska Fisheries Science Center/NOAA, 7600 Sand Point Way N.E., Seattle \\ Washington 98115-6349, USA \\ ${ }^{4}$ Institut de Recherche pour le Development, Centre de Recherche Halieutique Méditerranéenne et Tropicale, UMR 212, \\ Avenue Jean Monnet - BP 171, Sète Cedex, France
}

\begin{abstract}
In marine ecosystems, physical and biological processes act at multiple temporal and spatial scales to influence the distribution of prey species and subsequently habitat selection of foraging apex predators. Understanding how apex predators may respond to climate changes requires knowledge of habitat selection in relation to measures of foraging success at spatio-temporal scales relevant to the question and analytical approach. In this study, we used satellite telemetry from 75 adult female northern elephant seals Mirounga angustirostris, coupled with point measures of foraging success (energy gain), to examine habitat selection at large temporal and spatial scales. The main hydrographic ecoregion used on the post-moult (PM) migration was the Transition Zone, while on the post-breeding (PB) migration, females focused on the Subarctic Gyre. Characteristics of arearestricted search (ARS) behaviours, as determined by the fractal landscape method (such as time spent in ARS, total distance travelled in ARS and number of ARS) also differed significantly between the PM and PB migrations. Underlying differences in prey composition and/or distribution may drive the differences seen in searching behaviour and foraging success of elephant seals at large scales. Despite these differences, seals showed comparable levels of foraging success across both migrations and in all ecoregions. Foraging success was notably greater than measured in previous studies. These results highlight the benefits of a capital breeding strategy to a relatively slow-moving, large vertebrate predator allowing individuals to exploit large areas of the heterogeneous North Pacific.
\end{abstract}

KEY WORDS: Apex predator $\cdot$ North Pacific $\cdot$ Transition Zone $\cdot$ Subarctic Gyre $\cdot$ Habitat selection

\section{INTRODUCTION}

In marine systems, the importance of scale has long been recognised, with processes shaping the environment acting at several temporal and spatial scales (Steele 1988, Mann \& Lazier 1996). Aggregations of species also occur at different temporal and spatial scales relating to different environmental effects, from the aggregation of zooplankton at the thermocline (Russell et al. 1999) to aggregations of fishes, squid and other vertebrate predators within frontal systems (Lefevre 1986, Russell et al. 1999, Field et al. 2001, Polovina et al. 2001). Fronts have been shown to delineate species distributions (Brinton 1962, Beamish et al. 1999, Sassa et al. 2002), although the specific mechanisms responsible often require careful investigation (Sournia 1994). 
Three climate-scale hydrographic zones, or ecoregions, persist in the North Pacific (Fig. 1a). However, their seasonal locations vary (Fig. 1b), and at the boundaries between zones several fronts may occur at any time with mesoscale eddies and submesoscale jets contributing to complexity and creating patches of productive areas a few $\mathrm{km}$ across (Roden 1991). The 3 ecoregions and their 2 frontal boundary regions constitute 5 latitudinal zones of the North Pacific (Roden 1991) that have been shown to delineate species distributions of zooplankton (Brinton 1962) and fishes (Beamish et al. 1999, Sassa et al. 2002) and are of ecological importance to some apex predators (Polovina et al. 2000, Hyrenbach et al. 2002). One particular frontal system that has received a lot of attention is the Transition Zone Chlorophyll Front (TZCF, operationally defined at $0.2 \mathrm{mg} \mathrm{m}^{-3}$ ), which has been associated with
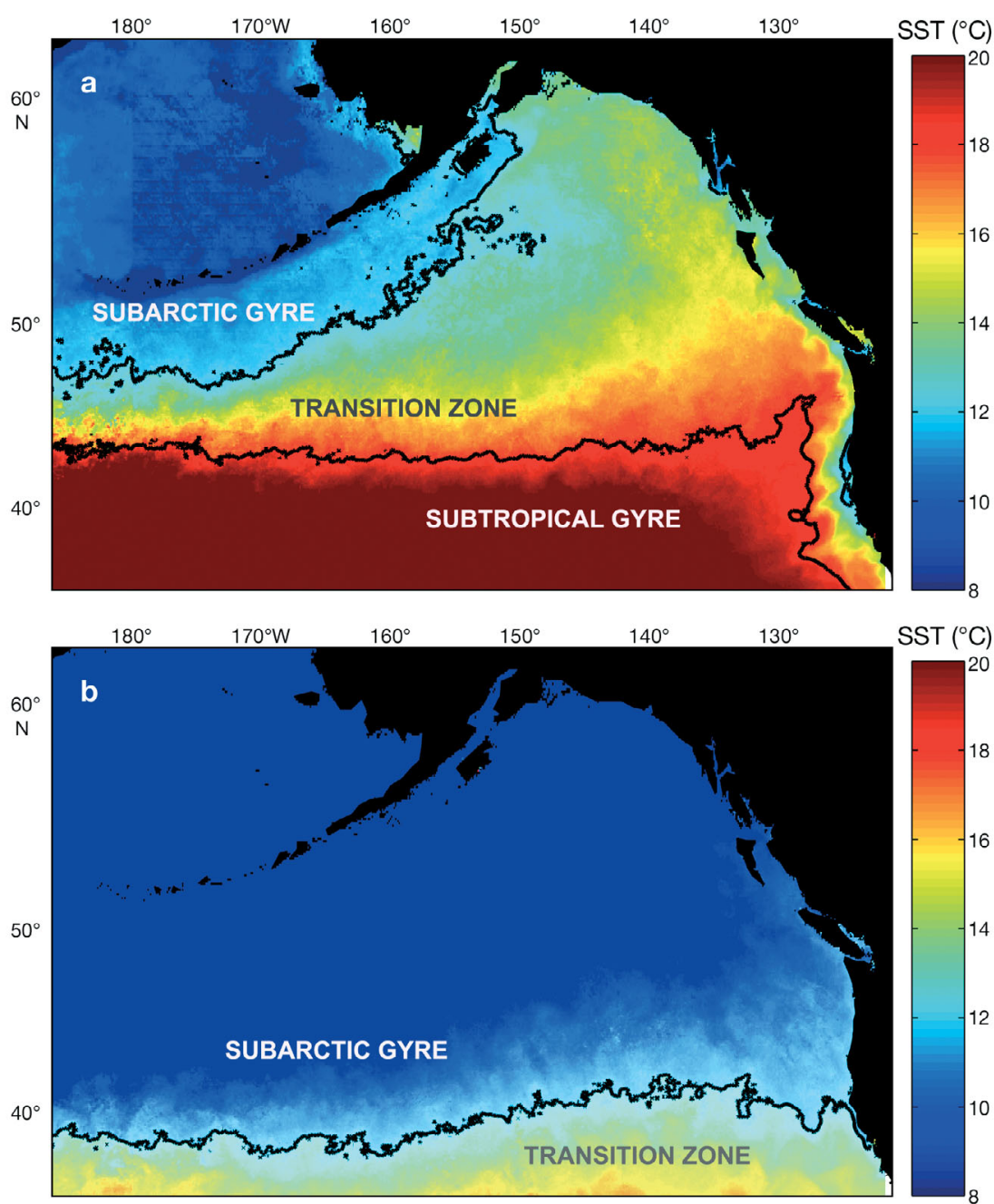

Fig. 1. Blended monthly $0.1^{\circ}$ sea surface temperature (SST) for (a) September 2005 and (b) April 2005. Data courtesy of NOAA's Environmental Research Division (http://coastwatch.pfeg.noaa.gov/coastwatch/CWBrowserWW360.jsp). Contours drawn at $12^{\circ} \mathrm{C}$ and $18^{\circ} \mathrm{C}$ delineate climate-scale hydrographic features following Longhurst (1998) and Weng et al. (2008) movement patterns of turtles and the distribution of albacore tuna (Polovina et al. 2001). The TZCF moves up to $1000 \mathrm{~km}$ in latitude annually but is usually contained within the climatological mean position of the Transition Zone (Roden 1991, Polovina et al. 2001, Bograd et al. 2004).

Although productivity increases with latitude in the North Pacific at macro scales, the mesoscale eddies shed in the frontal zones act to locally enhance productivity from intermediate temporal (weeks) and spatial scales (100s km), down to a few $\mathrm{km}$ (Roden 1991). To find food in a patchy environment such as this, animals utilise area-restricted search (ARS) patterns at various scales (Bell 1991). ARS patterns maximise the localisation of prey and time spent in areas with abundant resources and extend the search to larger areas when resources become scarce (Bell 1991, Hills et al. 2004). ARS behaviour is affected by the mobility of the animal, the distribution and quality of resources, and the physiological need of the animal (Bell 1991). Foraging success can be considered as maximisation of energy gain relative to time or energy spent searching for food. Within a patchy hierarchical system, such as the North Pacific, we expect to find different behavioural patterns at different operational scales (Bell 1991, Guinet et al. 2001, Hyrenbach et al. 2002). These patterns will be influenced by characteristics of the patch. For example, given a high density of high quality resources within a patch, we might expect an individual to spend more time searching in, or more effort to return to, this patch than a patch with lower density or quality of resources. By linking searching behaviour to measures of foraging success, such as mass or energy gain, we can ascertain the ecological significance of selected habitat and better understand potential impacts of climate change.

With the increased use of electronic instruments to remotely track large or wide-ranging animals, movement patterns and foraging behaviour can now be examined on global and multi-year time scales (Polovina et al. 2004, Block et al. 2005, Shaffer et al. 2006, Weng et al. 2008). Tracking characteristics such as turn angle, transit rate, and first passage time or fractal dimension have been used to examine the movement patterns of multiple marine species 
(Weimerskirch et al. 1994, Laidre et al. 2004, Robinson et al. 2007). These approaches are often used as a proxy for feeding success to identify areas important to foraging animals. Characterisation of the environment in these areas is therefore vital to understand which cues animals use to find food, and/or what features might be contributing to increased productivity. Both remotely sensed data (Polovina et al. 2000, Simmons et al. 2007) and in situ data from instruments carried by the animals themselves can be used to characterise their immediate environment (Hindell et al. 1991a, Lydersen et al. 2002). This information could then be used to model an animal's response to changes in its environment.

Northern elephant seals Mirounga angustirostris offer a unique opportunity to examine how an apex predator searches a complex environment for prey, as they spend up to 10 mo of the year ranging widely across the North Pacific, while continuously probing its subsurface structure to depths of 400 to $600 \mathrm{~m}$ every 20 min, on average (Le Boeuf et al. 1986, 1988, 2000). A female elephant seal's annual cycle is divided into 2 distinct periods of resource acquisition at sea and 2 periods of resource allocation on land for breeding and moulting. As capital breeders (Jönsson 1997), all of the resources that females allocate to reproduction are acquired during a single foraging trip (or post-moult [PM] migration) lasting up to 8 mo prior to breeding. Thus, foraging success on this migration has a direct influence on reproductive success as well as the condition of individual females.

Previous studies have identified areas of 'focal foraging effort' for elephant seals, based on a reduction in the mean daily transit rate, that were coincident with an increase in foraging-type dives as well as mass gain (a measure of foraging success) while at sea (Le Boeuf et al. 1988, 2000, Crocker et al. 2006) and considered these areas in relation to satellite-derived oceanographic features (Simmons et al. 2007). Adult females behave optimally with regard to time spent within a foraging patch versus travel time to that patch (Charnov 1976, Crocker et al. 2006). However, this relationship broke down during the 1997/98 El Niño and was accompanied by a significant decrease in mass gain, although animals still visited similar regions of the North Pacific (Crocker et al. 2006).

Crocker et al. (2006) suggested that El Niño conditions may alter the hydrography that helps determine prey patch characteristics, and thus females may respond to inappropriate oceanographic cues while searching for prey. The goals of our study were to examine searching behaviour and foraging success of adult female northern elephant seals relative to climate or macroscale hydrographic features of the North Pacific. We hypothesised that (1) searching behaviour (characteristics of ARS) will vary by ecoregion used, indicative of different prey species/distributions in each ecoregion; (2) female elephant seals will use different hydrographic ecoregions on their 2 annual foraging migrations; and (3) foraging success will vary, with higher rates of energy gain associated with more productive, higher latitude ecoregions.

\section{MATERIALS AND METHODS}

To examine the searching behaviour of adult female northern elephant seals, we used satellite transmitters to obtain at-sea locations from 75 migrations. Satellite and VHF transmitters were deployed from a colony at Año Nuevo State Reserve (San Mateo County, California, USA). Females were instrumented in April to June after the moult and transmitters were recovered in January to February (PM migrations; 2004: n = 19, 2005: $n=19$ ). Females were also instrumented in February to March following the breeding season and transmitters were recovered in April to May (postbreeding [PB] migrations; 2005: $\mathrm{n}=18,2006$ : $\mathrm{n}=19$ ).

Satellite transmitters used included Telonics ST-20 $(\mathrm{n}=2)$, Wildlife Computers Spot4 $(\mathrm{n}=52)$, and Sea Mammal Research Unit, Satellite Relay Data Loggers (SRDLs, $\mathrm{n}=21$ ). Each female was also equipped with a VHF radio tag (ATS) that allowed individual animals to be relocated upon return to the colony.

Animal handling. The seals were initially sedated using an intra-muscular injection of Telazol ${ }^{\circledR}$ at an estimated dose of $1 \mathrm{mg} \mathrm{kg}^{-1}$, and sedation was maintained with intravenous doses of ketamine and valium as necessary (Briggs et al. 1975, Baker et al. 1990).

Satellite transmitters were attached to the head of the seal using a quick-setting 5 min epoxy (Loctite ${ }^{\circledR}$ Quick Set ${ }^{\mathrm{TM}}$ Epoxy). Radio transmitters were attached on a single nylon mesh patch to the dorsal midline just posterior to the shoulder blades. While the females were sedated, blubber depth measurements were taken at 6 points on the dorsal, lateral and ventral sides using an ultrasound scanner accurate to $\pm 1 \mathrm{~mm}$ (Scanoprobe). Length and girth measurements were also taken at these points and used in a model of truncated cones to calculate total blubber mass as a percentage of body mass (Gales \& Burton 1987, Webb et al. 1998). Females were rolled onto a canvas sling, suspended from a carbon fibre tripod using a come-along and weighed using a Dyna-Link scale (1000 \pm 1 kg, Measurement Systems International).

Instruments were recovered when the females returned to the colony. Ultrasound, morphometrics and mass measurements were also collected at this time. For the PB migration, instruments were recovered as soon as possible following the female's return to the 
colony. Following the PM migration, females were resighted daily to establish an accurate pupping date, and instruments were not recovered until at least $5 \mathrm{~d}$ postpartum to allow the mother-pup bond to develop and to minimise the chance of separations.

As most females spent time on shore post deployment and/or pre-recovery, corrections were necessary to estimate mass at departure and arrival. This correction was based on equations derived from serial mass measurements of fasting female seals from previous studies (mass change $\left[\mathrm{kg} \mathrm{d}^{-1}\right]=0.51+0.0076 \times$ mass, $\mathrm{n}=27, \mathrm{r}^{2}=0.79, \mathrm{p}<0.01 ; \mathrm{D}$. Crocker \& D. Costa unpubl.). For PM recoveries, the mass of the pup at recovery was added to that of the female. Adipose and lean tissue gain was estimated from mass change and body composition, assuming body composition at arrival (or departure) was similar to that during the recovery (or deployment) and that the pup $5 \mathrm{~d}$ postpartum was $13 \%$ adipose tissue (Crocker et al. 2001).

Foraging success was measured as mass gain, energy gain or their respective rates across the entire migration. Energy gain was estimated assuming adipose tissue was $90 \%$ lipid and lean tissue was $27 \%$ protein (Crocker et al. 2001) and a gross energy content of $37.3 \mathrm{~kJ} \mathrm{~g}^{-1}$ for lipids and $23.5 \mathrm{~kJ} \mathrm{~g}^{-1}$ for protein. These estimates of body composition have been validated previously with dilution of isotopically labelled water (Webb et al. 1998).

Data handling. Satellite locations were obtained from Service Argos (Toulouse, France, and Landover, Maryland, USA) and were filtered using a basic speed filter of $10 \mathrm{~km} \mathrm{~h}^{-1}$ (McConnell et al. 1992). Alternate locations provided by Service Argos were used when appropriate. The resulting tracks were then interpolated every 5 min using a Bezier curve with $\mu=0.1$ following Tremblay et al. (2006). Interpolation was necessary for a more accurate calculation of fractal dimension along the tracks. Furthermore, interpolation of tracks based on multiple locations can actually be more accurate than the underlying individual locations due to noise averaging, especially when temporal separation between locations is small (Lonergan et al. 2009).

Tracking statistics, including total track length $(\mathrm{km})$, distal point from the colony $(\mathrm{km})$, track duration $(\mathrm{d})$ and mean transit rate $\left(\mathrm{km} \mathrm{h}^{-1}\right)$ were calculated from the interpolated tracks, and compared for differences between migrations and years.

The fractal landscape method was used to identify ARS for each interpolated track following the methods of Tremblay et al. (2007). This approach uses fractal geometry to quantify how well an animal's search pattern covers a region or plane of interest both spatially and temporally. Given this, we felt it necessary that all ARS contain at least 3 Argos location fixes, and we removed any ARS that contained less than 3 original, speed-filtered Argos locations. ARS were further modified, as Tremblay et al. (2007) noted that low numbers of raw ARGOS locations received per day may result in an overestimate of the area of ARS by a factor of up to 2.2 for elephant seals. To account for this, we corrected the radius of each ARS (and hence its area) using $y=-0.07908 x+2.605$, derived from the data presented by Tremblay et al. (2007), where $y=$ correction factor, and $x=$ mean number of raw ARGOS locations $\mathrm{d}^{-1}$ for each female. Several statistics representing searching behaviour were calculated for each ARS: number of ARS in each migration, time spent in ARS (d), distance travelled in ARS $(\mathrm{km})$, and area of ARS $\left(\mathrm{km}^{2}\right)$. These ARS characteristics were then compared to measures of energy gain.

Because the boundaries of climate scale hydrographic features move seasonally, ecoregions were assigned dynamically following Weng et al. (2008), based on Longhurst (1998). To determine which of the 3 latitudinal ecoregions females were using on each migration, we extracted a value of sea surface temperature (SST) for each ARS using the mean position of the ARS and the midpoint of time spent in that ARS. SST data were obtained from http:// coastwatch.pfeg.noaa.gov/coastwatch/CWBrowserWW 360.jsp and were blended over $5 \mathrm{~d}$ at a spatial scale of $0.1^{\circ}$ from multiple sources, comprising Moderate Resolution Imaging Spectroradiometer (MODIS), Advanced Very High Resolution Radiometer (AVHRR) Imager, the Advanced Microwave Scanning Radiometer (AMSR-E) and NOAA's Geostationary Operational Environmental Satellite (GOES) Imagers. We assigned ARS to the Subarctic Gyre (SAG) if SST $\leq$ $12^{\circ} \mathrm{C}_{i}$ the Transition Zone (TZ) if SST was 12.1 to $17.9^{\circ} \mathrm{C}$; and the Subtropical Gyre (STG) if SST $\geq$ $18^{\circ} \mathrm{C}$ (Longhurst 1998). Neritic regions were defined by their proximity to the coast, with the Coastal Alaska Downwelling Region (CADR) being waters within $150 \mathrm{~km}$ of the coast and north of $48^{\circ} \mathrm{N}$, and the California Current Upwelling Region (CCUR) south of $48^{\circ} \mathrm{N}$ and up to $1000 \mathrm{~km}$ from the coast at the southern margin, and $500 \mathrm{~km}$ from the coast at the northern margin (Longhurst 1998). Each female was designated to a single ecoregion based on the ecoregion in which she spent the greatest total time in ARS.

Analyses. Annual differences and differences between migrations in foraging success, tracking statistics and ARS characteristics were examined using linear mixed models with individual seal as a random effects 'subject' term. Model residuals were examined for approximate normality for all tests. Processing of tracking and environmental data was done using Matlab (Mathworks), and all models were run using SAS software, Version 9.1 of the SAS System for Windows. 


\section{RESULTS}

From 75 deployments, 6 females failed to return to the colony and none of these animals has been sighted at Año Nuevo since. Of the remaining 69 deployments, 6 collected very little or no tracking data. Ultrasound (and hence energy gain measurements) were not collected for 2 females, and a further 9 failed to exhibit ARS behaviour and were removed from the analysis. This resulted in a dataset of ARS with accompanying measures of foraging success from 52 adult female northern elephant seals (PM $2004=$ 14, PB $2005=11$, PM $2005=16, \mathrm{~PB}$ $2006=11)$

\section{Foraging success}

Mass and energy gain were significantly greater during the PM migration $(282 \pm 38 \mathrm{~kg}$ and $4444 \pm 642 \mathrm{MJ}$, respectively) than the $\mathrm{PB}$ migration $\left(77 \pm 19 \mathrm{~kg}\right.$ and $1254 \pm 483 \mathrm{MJ}_{;} F_{1,2}=$ 197.4, $\mathrm{p}<0.005$ mass gain and $F_{1,2}=$ 185.1, p < 0.01, energy gain). Due to the significant difference between migrations and because of the temporal distribution of sampling periods, annual comparisons were made only within migration (i.e. PB or PM). Thus, we limited comparisons to PM 2004: PM 2005 and PB 2005: PB 2006 when investigating annual effects.

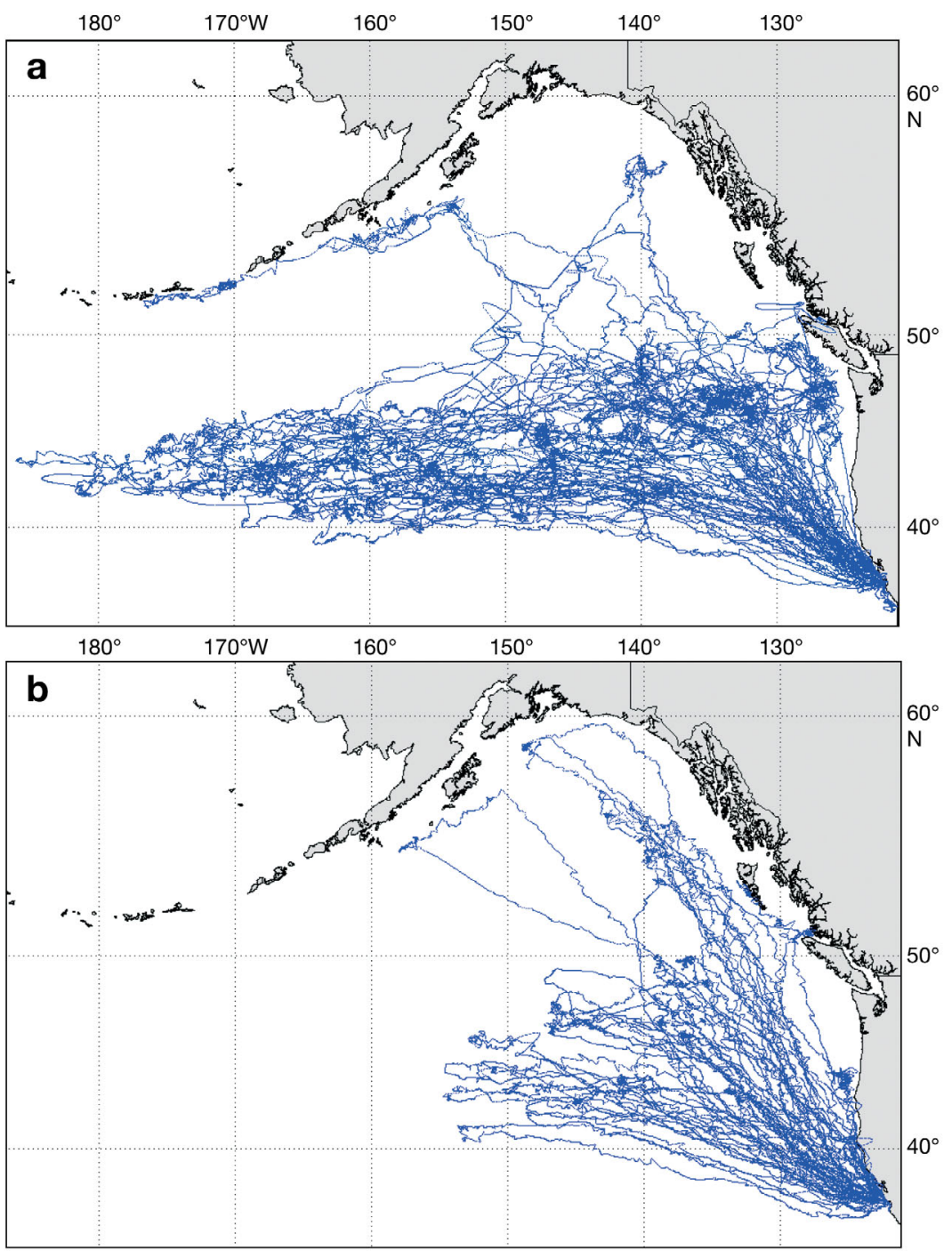

Fig. 2. Mirounga angustirostris. Satellite tracks for (a) all post-moult (PM) females $(\mathrm{n}=33)$ between 2004 and 2005 and (b) all post-breeding (PB) females $(\mathrm{n}=30)$ between 2005 and 2006

\section{Tracking, ARS and ecoregions}

Satellite data from 52 females were used to calculate basic tracking statistics. Total track length and distal point from the rookery were significantly greater during the PM migration than the PB migration (Table 1, Fig. $2 ; F_{1,2}=90.0, \mathrm{p}=0.01$, and $\left.F_{1,2}=17.68, \mathrm{p}<0.05\right)$.
Transit rates were significantly greater during the PB than the PM migration (Table 1, $F_{1,2}=34.7, \mathrm{df}=1, \mathrm{p}=$ 0.03).

In total, 283 ARS were identified following Tremblay et al. (2007). Time spent in ARS $\left(F_{1,2}=629.0, \mathrm{p}<0.001\right)$ and the distance travelled within ARS $\left(F_{1,2}=28.5, \mathrm{p}=\right.$ 0.03 ) were significantly greater during the PM than the

Table 1. Mirounga angustirostris. Summary statistics (mean \pm SD) for 52 females on their post-moult (PM) and post-breeding (PB) migrations for foraging success, tracking statistics and area-restricted search (ARS) statistics

\begin{tabular}{|lcccccccccc}
\hline Migration & $\begin{array}{c}\text { Trip } \\
\text { duration } \\
(\mathrm{d})\end{array}$ & $\begin{array}{c}\text { Mass } \\
\text { gain } \\
(\mathrm{kg})\end{array}$ & $\begin{array}{c}\text { Energy } \\
\text { gain } \\
(\mathrm{MJ})\end{array}$ & $\begin{array}{c}\text { Total track } \\
\text { length } \\
(\mathrm{km})\end{array}$ & $\begin{array}{c}\text { Distal } \\
\text { point } \\
(\mathrm{km})\end{array}$ & $\begin{array}{c}\text { Mean } \\
\text { transit rate } \\
\left(\mathrm{km} \mathrm{d}^{-1}\right)\end{array}$ & $\begin{array}{c}\text { No. } \\
\text { of } \\
\text { ARS }\end{array}$ & $\begin{array}{c}\text { Time } \\
\text { in ARS } \\
(\mathrm{d})\end{array}$ & $\begin{array}{c}\text { Distance } \\
\text { travelled in } \\
\text { ARS }(\mathrm{km})\end{array}$ & $\begin{array}{c}\text { Area } \\
\text { of ARS } \\
\left.(\mathrm{km})^{2}\right)\end{array}$ \\
\hline PM & $224 \pm 13$ & $282 \pm 38$ & $4444 \pm 642$ & $12578 \pm 2291$ & $3236 \pm 1057$ & $2.52 \pm 0.61$ & $7 \pm 3$ & $4.42 \pm 2.48$ & $178 \pm 67$ & $395 \pm 216$ \\
PB & $79 \pm 8$ & $77 \pm 19$ & $1254 \pm 483$ & $6954 \pm 1247$ & $2266 \pm 525$ & $3.75 \pm 0.54$ & $3 \pm 2$ & $2.44 \pm 1.44$ & $166 \pm 75$ & $653 \pm 471$ \\
\hline
\end{tabular}


PB migrations. There was no difference in the number of ARS $\left(F_{1,2}=15.62, \mathrm{p}=0.06\right)$ between migrations, but the spatial extent of ARS (area of circle) was larger on the PB than the PM migration (Table 1, Fig. 3, $F_{1,2}=$ $7.55 \mathrm{p}=0.01$ ). There were no significant annual differences found for any of the variables examined; hence, both years of PM and PB data were combined and considered together for all other analyses.

Locations of ARS revealed the TZ as an important basin-scale hydrographic feature for females on their PM trip, as $65 \%$ of ARS on this migration occurred in the TZ (Fig. 3a). During PB migrations, the SAG was the most extensively used hydrographic ecoregion

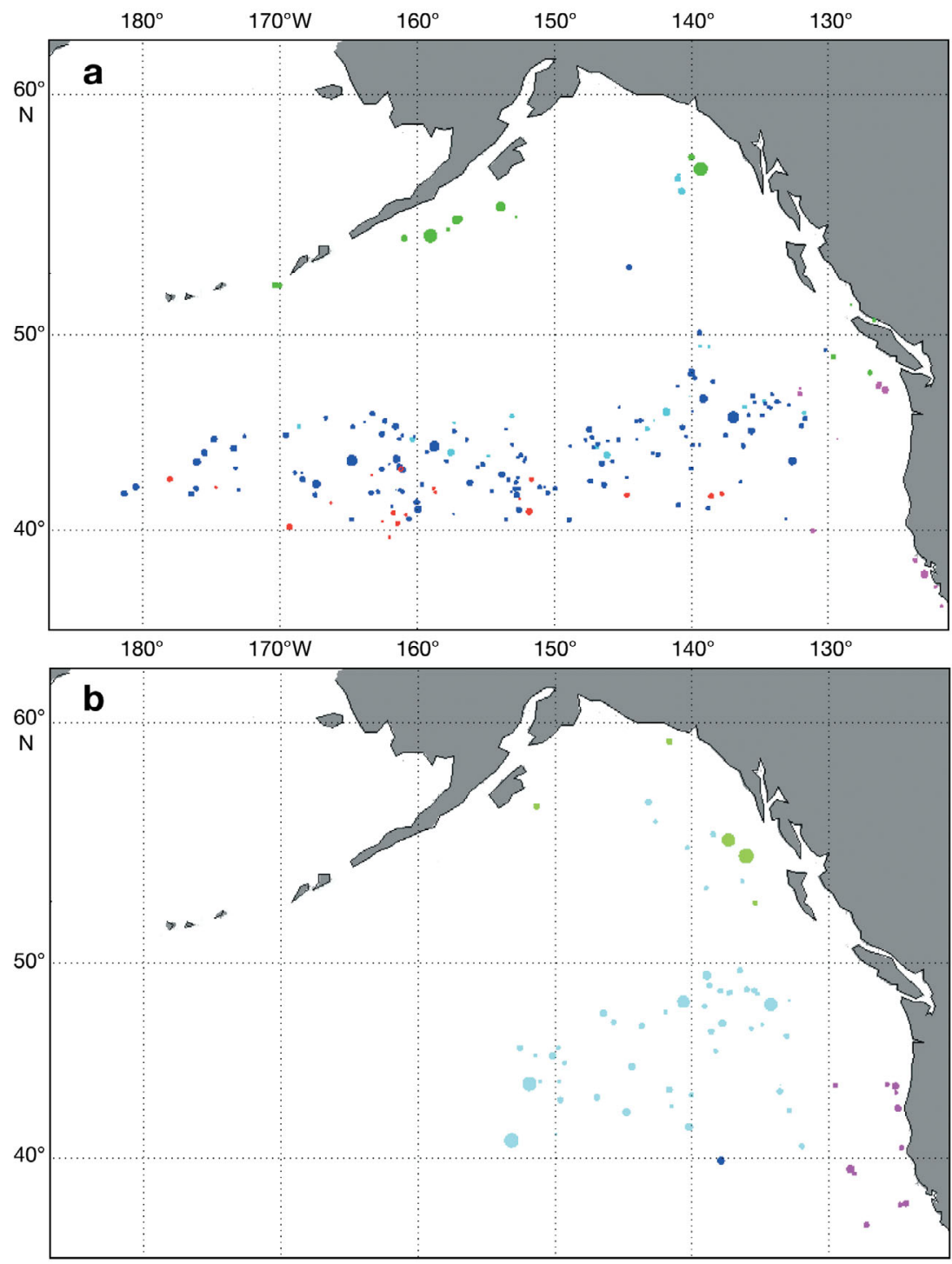

Fig. 3. Mirounga angustirostris. All area-restricted searches (ARS) from (a) 30 post-moult (PM) migrations and (b) 22 post-breeding (PB) migrations. Each circle represents $1 \mathrm{ARS}$, and the circle area is proportional to the area covered by the ARS. Colours indicate ecoregion. Red: Subtropical Gyre (STG), blue: Transition Zone (TZ), cyan: Subarctic Gyre (SAG), magenta: California Current Upwelling Region (CCUR), green: Coastal Alaska Downwelling Region (CADR)
(74\% of ARS on this migration, Fig. 3). Total time spent in ARS was significantly correlated with energy gain (Fig. 4), but migration was found to have a significant and dominant effect on this result (analysis of covariance [ANCOVA], $F_{1,2}=90.34, \mathrm{p}<0.001$ ). When controlling for migration, the relationship between time spent in ARS and total energy gain was not significant for PB ( $p=0.89)$ or PM ( $p=0.17)$ data (Fig. 4). The strong effects of migration may be an artefact of the longer duration of the PM migration. To account for this, we considered the rate of energy gain in relation to hydrographic ecoregion. There were no differences among rates of energy gain $\left(\mathrm{MJ} \mathrm{d}^{-1}\right)$ and the ecoregion in which ARS were located (Fig. 5). However, the lowest variability in rates of energy gain was evident when ARS were focused in the $\mathrm{TZ}$, and the highest variability in rates of energy gain when ARS were focused in the SAG (Fig. 5).

\section{DISCUSSION}

\section{Foraging success}

There was wide variability in foraging success that was independent of location or ARS characteristics. Foraging success was greater during the PM migration than the PB migration, as has been found previously (Le Boeuf et al. 2000). Females in the current study also displayed rates of mass gain during the short PB migration similar to what Le Boeuf et al. (2000) found for mean rate of mass gain during long PM migrations between 1995 and 1997 (0.96 kg d ${ }^{-1}$ ). This may reflect an upswing in female mass gain, perhaps in sync with postulated improved foraging success associated with the cold water regime of the Pacific Decadal Oscillation (Le Boeuf \& Crocker 2005).

\section{Tracking, ARS and ecoregions}

We hypothesised that searching behaviour (characteristics of ARS) would vary by ecoregion used, possibly indicating different prey species distributions in each ecoregion. We found that females ranged farther on their PM migrations than their PB migrations (Figs. 2 \& 3). Although these differences 


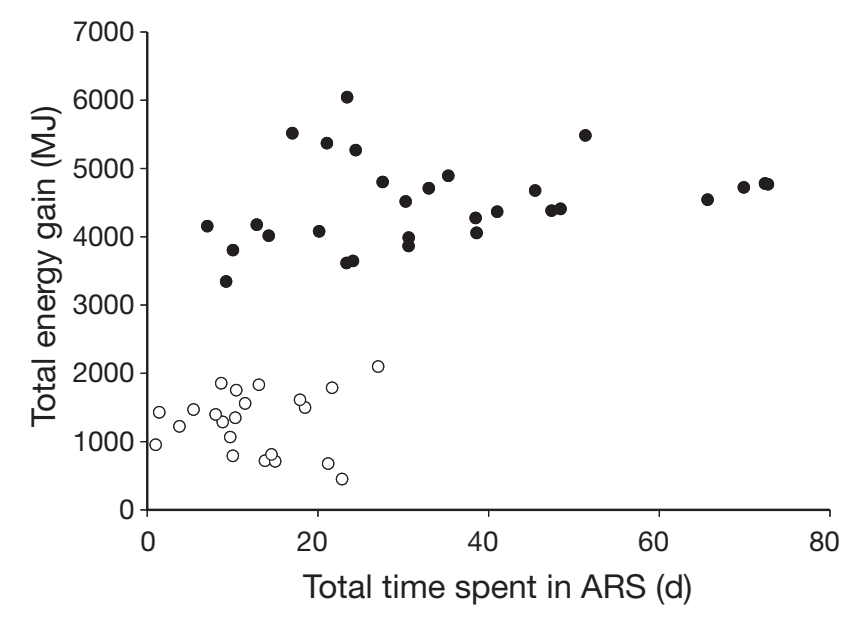

Fig. 4. Mirounga angustirostris. Significant relationship between total time at sea spent in area-restricted search (ARS) and total energy gain for all ARS on both migrations $(y=$ $\left.1713.53+5643 x, \mathrm{r}^{2}=0.37, F=29.10, \mathrm{df}=1, \mathrm{p}<0.0001\right)$. However, analyses of covariance revealed that migration (post-moult [PM, $\bullet$; post-breeding [PB, 이) drives this relationship and, when considered by migration, total time in ARS was not significantly correlated to total energy gain (PB: $y=1261.80+1.94 x, \mathrm{r}^{2}=0.0009, F=0.02, \mathrm{df}=1, \mathrm{p}=0.89$. PM: $y=4195.62+8.68 x, \mathrm{r}^{2}=0.07, F=1.96, \mathrm{df}=1, \mathrm{p}=0.17$ )

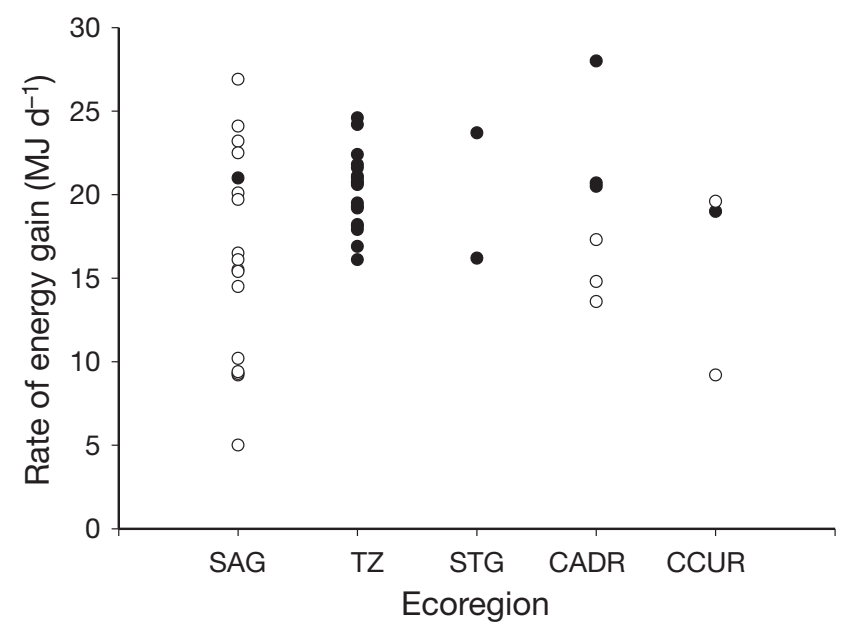

Fig. 5. Mirounga angustirostris. Variation in rates of energy gain for post-moult $(\mathrm{PM}, \bullet)$ and post-breeding $(\mathrm{PB}, \mathrm{O})$ migrations, in relation to ecoregion. SAG: Subarctic Gyre, TZ: Transition Zone, STG: Subtropical Gyre, CADR: Coastal Alaska Downwelling Region, CCUR: California Current Upwelling Region. Each dot represents a single female that was assigned to a single ecoregion based on greatest total time spent in area-restricted search (ARS)

are likely an artefact of the shorter duration of the PB migration whicch did not give females enough time to exploit more distant areas, transit rates were higher on the PB than the PM migrations, implying that females could cover more ground than expected on the PB migration by just comparing days at sea. However, higher transit rates may be related to the lower foraging suc- cess seen on the PB migration. If females fail to find adequate prey patches, an overall increase in transit rate would be expected. Both Le Boeuf et al. (2000) and Kuhn et al. (2009) have shown that slow transit rates correlate with increased foraging success in this species.

Females exhibited fewer ARS on the PB migration than the PM migration. Perhaps with less time to find subsequent patches, females increase their searching effort within a smaller number of patches on the PB migration. Interestingly, females travelled significantly farther within ARS on the longer PM trip than on the shorter PB trip, but ARS covered a significantly larger area on the PB than the PM migration (Table 1). The distribution of resources within a patch will affect the way a female searches for prey. The females did not spend more time in ARS on the PB migration (Table 1); thus, it is possible that resources are less aggregated at this time of year and females employ a different searching strategy to obtain sufficient resources. Some of these strategies are successful; rate of energy gain on the PB migration can be similar to that of the PM migration (Fig. 5). Thus, characteristics of searching behaviour did vary by ecoregion used, but the results were highly dependent on whether the female was on her PB or PM migration.

The distinct change in searching behaviour and positive trend between time in ARS and foraging success on PM migrations (Fig. 4) imply that ARSs represent important foraging regions for female elephant seals. However, determination of their exact ecological significance will require further investigation. Our results indicate that ARS were not pivotal to foraging success, as neither mass nor energy gain (Fig. 4) were significantly correlated with an increased time spent in ARS. Weimerskirch et al. (2007) also found a lack of correlation between ARS and feeding events when using a direct measure of feeding, stomach temperature telemetry, and high quality GPS tracking data in wandering albatrosses Diomedea exulans. Additionally, Bestley et al. (2008) found no relationship between direct measures of feeding and time spent within a given area in southern bluefin tuna Thunnus maccoyii. It is possible that ARS regions do not represent the only areas important for foraging success of apex predators in a patchy environment. In fact, Weimerskirch et al. (2007) found that over $75 \%$ of feeding events of albatross occurred outside ARS.

Differences between migrations were seen with respect to hydrographic ecoregions utilised by the females (Fig. 3), supporting our second hypothesis. However, the switch from most females using the TZ on their PM migration, to use of the SAG on the PB migration may simply be a result of the dynamic availability of these ecoregions relative to the location of the 
colony, rather than an explicit choice of females for a particular ecoregion. This assertion is supported by the geographic overlap of the tracking data between migrations (Fig. 2). Additionally, with less time at sea on the PB migrations to acquire resources, females finding patches closer to the colony did not venture farther offshore to the TZ. Given the longer duration of PM migrations, females were able to venture farther in search of more productive patches. Four females exclusively used the TZ on their PM migrations, implying that perhaps some females identify this as a productive feature and may take a direct route to exploit this region. A higher use of more distant frontal zones has been shown in least auklets Aethia pusilla, presumably due to higher densities of preferred prey species at the front, rather than an absence of suitable prey species closer to shore (Russell et al. 1999). Within the TZ, one or several fronts may occur at any given time, and there can be large variability in the mesoscale hydrostatic stability in the upper ocean in this zone (Roden 1991). Frontal zones are known to concentrate nutrients and aggregate fish and squid (Lefevre 1986, Russell et al. 1999), an important elephant seal prey source (Condit \& Le Boeuf 1984, Antonelis et al. 1987), as well as other vertebrate predators (Field et al. 2001, Polovina et al. 2001). The heterogeneity of the TZ makes it an efficient resource to exploit because an individual will not have far to travel before encountering a new patch. Mesoscale eddies in this region act to locally enhance productivity at intermediate temporal and spatial scales, and submesoscale vortices on the flanks of transient jets may create productive patches on the order of a few $\mathrm{km}$ (Roden 1991). This environmental heterogeneity creates habitat diversity for potential prey of elephant seals, including fish and squid, given their thermal tolerances and preferences (Brandt 1981, 1983, 1993). Indeed, diversity of fish larvae has been shown to be highest in the TZ and lowest in the SAG (Norcross et al. 2003).

In contrast, although the SAG contains several mesoscale, anti-cyclonic eddies such as the Haida and Sitka eddies (Tabata 1982, Musgrave et al. 1992, Crawford 2002) that enhance production (Whitney \& Robert 2002, Crawford et al. 2005) and may be important features for foraging elephant seals (Simmons et al. 2007), they are also more patchily distributed relative to the lower amplitude mesoscale eddy field of the TZ (Roden 1991). Thus, there may be a strategic trade-off between a low encounter rate of potentially higher quality patches in the SAG and a high encounter rate of potentially lower quality patches in the TZ. This trade-off may be particularly relevant to a capital breeder such as the northern elephant seal and may at least partially explain the differences seen in the variability of success in adult females between these 2 regions (Fig. 5).
Our third hypothesis, that foraging success would vary with higher rates of energy gain associated with more productive, higher latitude ecoregions, was not supported by our results; overall, females using the SAG did not show higher rates of mass gain than females using the TZ (Fig. 5). However, there was greater variability in rates of energy gain during the $\mathrm{PB}$ migration, when the females were using the SAG almost exclusively, than during the PM migration, when the TZ was primarily used (Fig. 5). This could be explained by and could highlight the advantages of a capital breeding strategy. On the PB migration, the females have to contend with a combination of less time at sea foraging and a greater threat of 'boom or bust' given the more patchy distribution of resources in the SAG described above. Meanwhile, as females have up to 8 mo to amortise energy requirements on the PM migration, the end result may be lower variability in rates of energy gain. Alternatively, the lower variability may be due to the use of the TZ, with a higher encounter rate of lower quality patches, by most females at this time of year. Either explanation highlights the value of a capital breeding strategy in an organism exploiting an environment with a patchy distribution of resources.

It has been previously noted that only a few females forage in the coastal zone, but interestingly, their foraging success is often comparable to that of the much larger adult males (Le Boeuf et al. 2000, Simmons et al. 2007). In this study, only 9 females exhibited ARS primarily in coastal zones, and these zones were exploited on both migrations (Fig. 5). Although one of these females did show the greatest rate of energy gain of any animal in the study, in general, success of females using coastal zones did not significantly differ from that of females using other ecoregions on either migration. Coastally foraging females remain rare in this population, and while several reasons for this have been proposed, including competition with males and/ or increased risk of predation on the continental shelf (Le Boeuf \& Crocker 1996, Le Boeuf et al. 2000), there has been no explicit investigation of these ideas.

\section{Other predators in the North Pacific}

Comparison of tracking data from northern elephant seals to other apex predators using the North Pacific might suggest significant overlap in habitat selection and potentially high levels of interspecific competition. For example, tracks from salmon sharks Lamna ditropis (Weng et al. 2008), Laysan Phoebastria immutabilis and black-footed albatross P. nigripes (Hyrenbach et al. 2002) and loggerhead turtles Caretta caretta (Polovina et al. 2000, 2001) all reveal that these predators 
spend time in overlapping pelagic and coastal areas of the North Pacific.

Weng et al. (2008) found that, in contrast to the elephant seals in our study, time spent by salmon sharks in both the CADR and the CCUR was likely important for foraging, while the sharks mainly transited through the SAG and TZ pelagic ecoregions. The ecological significance of these large-scale ecoregions for Laysan and black-footed albatrosses varies between species and with their annual reproductive cycles. During the brooding period, the STG is primarily used by blackfooted albatrosses, while Laysan albatrosses focus their foraging efforts in the colder TZ region (Hyrenbach et al. 2002). During the chick-rearing period, black-footed albatrosses exploit the CCUR, whereas Laysan albatrosses venture further north to the SAG and northern TZ (Hyrenbach et al. 2002). The physical-biological coupling that may be driving these patterns was found to be scale-dependent and highlighted the need to examine behaviours at both macromega scales (100 to $>10000 \mathrm{~km}$ ) and coarse mesoscales $(\sim 100 \mathrm{~km})$ to understand underlying water mass distribution, as well as recognising smaller features that may be locally enhancing productivity and aggregating prey (Hyrenbach et al. 2002). Loggerhead turtles apparently follow specific frontal features of the $\mathrm{TZ}$, such as the TZCF (operationally defined at $0.2 \mathrm{mg} \mathrm{m}^{-3}$; Polovina et al. 2001), or specific thermal fronts within the TZ (Polovina et al. 2000), deriving all necessary resources from aggregations of prey at these frontal structures.

Although a simple comparison of tracking data may indicate species overlap and potential competition, a closer examination of the ecological significance of the different zones to each organism reveals the importance of scale and the complexity of the marine ecosystem and highlights the challenges of predicting responses of such predators to local, seasonal, annual and inter-decadal climate changes.

\section{CONCLUSIONS}

Hydrographic ecoregions of the North Pacific used by female elephant seals on each of their foraging migrations were identified and linked with foraging success measured by mass and energy gain. There was wide variability in foraging success that was independent of geographic location but was likely driven by the hydrographic ecoregion used and was highly influenced by migration. Lower variability in rates of energy gain on the PM migration highlights the benefit of a capital breeding strategy when foraging in a heterogeneous and dynamic system. Operating over broader temporal and spatial scales in this environ- ment, females were able to recover body condition and obtain resources to sustain them through the next fasting period using a variety of ecoregions and searching strategies. Identification of ARS areas was invaluable as a starting point to consider the successful use of the North Pacific by adult females in relation to the major hydrographic ecoregions, and a vital first step to further our understanding of habitat selection and potential responses to climate change in this wide-ranging apex predator.

Acknowledgements. We thank K. Weng, D. Foley and D. Palacios for assistance with sea surface temperature (SST) analysis and identification of ecoregions, and acknowledge invaluable field assistance from B. McDonald, P. Morris, S. Villegas, D. Houser, A. Allen, S. Seganti, N. Udea, C. Barcelo, Y. Mitani, K. Yoda, E. Segeshio and S. Daugherty. Research and logistic support was funded by grants to S.E.S. from the Earl and Ethel Myers Oceanographic Trust and Friends of Long Marine Lab and to D.P.C. from the Office of Naval Research (ONR), National Oceanographic Partnership Program (NOPP) and Tagging of Pacific Predators (TOPP) through the Moore, Packard and Sloan Foundations. All research was conducted in accordance with institutional, national and international guidelines concerning the use of animals in research. Research was conducted under NMFS permit no. 836, and animal handling procedures were approved by the Chancellor's Animal Research Committee (IACUC) UC Santa Cruz.

\section{LITERATURE CITED}

Antonelis GA, Lowry MS, Demaster DP, Fiscus CH (1987) Assessing northern elephant seal feeding-habits by stomach lavage. Mar Mamm Sci 3:308-322

Baker JR, Fedak MA, Anderson SS, Arnbom T, Baker R (1990) Use of a tiletamine-zolazepam mixture to immobilize wild gray seals and southern elephant seals. Vet Rec 126:75-77

Beamish RJ, Leask KD, Ivanov OA, Balanov AA, Orlov AM, Sinclair B (1999) The ecology, distribution, and abundance of midwater fishes of the Subarctic Pacific gyres. Prog Oceanogr 43:399-442

Bell WJ (1991) Searching behaviour: the behavioural ecology of finding resources. Chapman \& Hall, New York, NY

> Bestley S, Patterson TA, Hindell MA, Gunn JS (2008) Feeding ecology of wild migratory tunas revealed by archival tag records of visceral warming. J Anim Ecol 77:1223-1233

Block BA, Teo SLH, Walli A, Boustany A and others (2005) Electronic tagging and population structure of Atlantic bluefin tuna. Nature 434:1121-1127

Bograd SJ, Foley DG, Schwing FB, Wilson C and others (2004) On the seasonal and interannual migrations of the transition zone chlorophyll front. Geophys Res Lett 31: L17204, doi:10.1029/2004GL020637

Brandt SB (1981) Effects of a warm-core eddy on fish distributions in the Tasman Sea off east Australia. Mar Ecol Prog Ser 6:19-33

> Brandt SB (1983) Pelagic squid associations with a warm-core eddy of the East Australian Current. Aust J Mar Freshw Res 34:573-585

$>$ Brandt SB (1993) The effect of thermal fronts on fish growth a bioenergetics evaluation of food and temperature. Estuaries 16:142-159

Briggs GD, Henrickson RV, Leboeuf BJ (1975) Ketamine 
immobilization of northern elephant seals. J Am Vet Med Assoc 167:546-548

Brinton E (1962) The distribution of Pacific euphausids. Bull Scripps Inst Oceanogr Univ Calif La Jolla 8:51-270

Charnov EL (1976) Optimal foraging, marginal value theorem. Theor Popul Biol 9:129-136

$>$ Condit R, Le Boeuf BJ (1984) Feeding-habits and feeding grounds of the northern elephant seal. J Mammal 65: 281-290

Crawford WR (2002) Physical characteristics of Haida Eddies. J Oceanogr 58:703-713

C Crawford WR, Brickley PJ, Peterson TD, Thomas AC (2005) Impact of Haida Eddies on chlorophyll distribution in the eastern Gulf of Alaska. Deep-Sea Res II 52:975-989

Crocker DE, Williams JD, Costa DP, Le Boeuf BJ (2001) Maternal traits and reproductive effort in northern elephant seals. Ecology 82:3541-3555

Crocker D, Costa DP, Le Boeuf BJ, Webb PM, Houser DS (2006) Impact of El Niño events on the foraging behavior of female northern elephant seals. Mar Ecol Prog Ser 309: $1-10$

Field I, Hindell M, Slip D, Michael K (2001) Foraging strategies of southern elephant seals (Mirounga leonina) in relation to frontal zones and water masses. Antarct Sci 13: 371-379

Gales NJ, Burton HR (1987) Ultrasonic measurement of blubber thickness of the southern elephant seal, Mirounga leonina (Linn). Aust J Zool 35:207-217

Guinet C, Dubroca L, Lea Mary A, Goldsworthy S and others (2001) Spatial distribution of foraging in female Antarctic fur seals Arctocephalus gazella in relation to oceanographic variables: a scale-dependent approach using geographic information systems. Mar Ecol Prog Ser 219:251-264

Hills T, Brockie PJ, Maricq AV (2004) Dopamine and glutamate control area-restricted search behavior in Caenorhabditis elegans. J Neurosci 24:1217-1225

> Hindell MA, Burton HR, Slip DJ (1991a) Foraging areas of southern elephant seals Mirounga leonina as inferred from water temperature data. Aust J Mar Freshw Res 42: $115-128$

> Hyrenbach KD, Fernandez P, Anderson David J (2002) Oceanographic habitats of two sympatric North Pacific albatrosses during the breeding season. Mar Ecol Prog Ser 233:283-301

Jönsson KI (1997) Capital and income breeding as alternative tactics of resource use in reproduction. Oikos 78:57-66

Kuhn CE, Crocker DE, Tremblay Y, Costa DP (2009) Time to eat: measurements of feeding behaviour in a large marine predator, the northern elephant seal (Mirounga angustirostris). J Anim Ecol 78:513-523

Laidre KL, Heide-Jorgensen MP, Logsdon ML, Hobbs RC, Dietz R, VanBlaricom GR (2004) Fractal analysis of narwhal space use patterns. Zoology (Jena) 107:3-11

Le Boeuf BJ, Crocker DE (1996) Diving behavior of elephant seals: implications for predator avoidance. In: P. Klimley (ed) Great white shark: the biology of Carcharodon charcharias. Academic Press, San Diego, CA, p 193-205

Le Boeuf BJ, Crocker DE (2005) Ocean climate and seal condition. BMC Biol 3:9

Le Boeuf BJ, Costa DP, Huntley AC, Kooyman GL, Davis RW (1986) Pattern and depth of dives in northern elephant seals, Mirounga angustirostris. J Zool 208:1-7

$>$ Le Boeuf BJ, Costa DP, Huntley AC, Feldkamp SD (1988) Continuous, deep diving in female northern elephant seals, Mirounga angustirostris. Can J Zool 66:446-458

> Le Boeuf BJ, Crocker DE, Costa DP, Blackwell SB, Webb PM, Houser DS (2000) Foraging ecology of northern elephant seals. Ecol Monogr 70:353-382

> Lefevre J (1986) Aspects of the biology of frontal systems. Adv Mar Biol 23:163-299

> Lonergan M, Fedak MA, McConnell BJ (2009) The effects of interpolation error and location quality on animal track reconstruction. Mar Mamm Sci 25:275-282

Longhurst AR (1998) Ecological geography of the sea. Academic Press, San Diego, CA

> Lydersen C, Nost OA, Lovell P, McConnell B and others (2002) Salinity and temperature structure of a freezing arctic fjord - monitored by white whales (Delphinapterus leucas). Geophys Res Lett 29:2119

Mann KH, Lazier JRN (1996) Dynamics of marine ecosystems: biological-physical interactions in the oceans. Blackwell Science, Maiden, MA

> McConnell BJ, Chambers C, Fedak MA (1992) Foraging ecology of southern elephant seals in relation to the bathymetry and productivity of the Southern Ocean. Antarct Sci 4:393-398

Musgrave DL, Weingartner TJ, Royer TC (1992) Circulation and hydrography in the northwestern Gulf of Alaska. Deep-Sea Res A 39:1499-1519

> Norcross BL, McKinnell SM, Frandsen M, Musgrave DL, Sweet SR (2003) Larval fishes in relation to water masses of the Central North Pacific Transitional Areas, including the shelf break of west-central Alaska. J Oceanogr 59: $445-460$

Polovina JJ, Kobayashi DR, Parker DM, Seki M P, Balazs GH (2000) Turtles on the edge: movement of loggerhead turtles (Caretta caretta) along oceanic fronts, spanning longline fishing grounds in the central North Pacific, 19971998. Fish Oceanogr 9:71-82

Polovina JJ, Howell E, Kobayashi DR, Seki MP (2001) The transition zone chlorophyll front, a dynamic global feature defining migration and forage habitat for marine resources. Prog Oceanogr 49:469-483

Polovina JJ, Balazs GH, Howell EA, Parker DM, Seki MP, Dutton PH (2004) Forage and migration habitat of loggerhead (Caretta caretta) and olive ridley (Lepidochelys olivacea) sea turtles in the central North Pacific Ocean. Fish Oceanogr 13:36-51

Robinson PW, Tremblay Y, Crocker DE, Kappes MA and others (2007) A comparison of indirect measures of feeding behaviour based on ARGOS tracking data. Deep-Sea Res II 54:356-368

Roden GI (1991) Subarctic-Subtropical Transition Zone of the North Pacific. Large-scale aspects and mesoscale structure. NOAA (Nat Ocean Atmos Adm) Tech Rep (Nat Mar Fish Ser) 105:1-38

Russell RW, Harrison NM, Hunt GL (1999) Foraging at a front: hydrography, zooplankton, and avian planktivory in the northern Bering Sea. Mar Ecol Prog Ser 182:77-93

Sassa C, Kawaguchi K, Kinoshita T, Watanabe C (2002) Assemblages of vertical migratory mesopelagic fish in the transitional region of the western North Pacific. Fish Oceanogr 11:193-204

- Shaffer SA, Tremblay Y, Weimerskirch H, Scott D and others (2006) Migratory shearwaters integrate oceanic resources across the Pacific Ocean in an endless summer. Proc Natl Acad Sci USA 103:12799-12802

Simmons SE, Crocker DE, Kudela RM, Costa DP (2007) Linking foraging behavior of the northern elephant seal with oceanography and bathymetry at mesoscales. Mar Ecol Prog Ser 346:265-275

Sournia A (1994) Pelagic biogeography and fronts. Prog Oceanogr 34:109-120

Steele JH (1988) Scale selection for biodynamic theories. In: 
Rothschild BJ (ed) Toward a theory on biological-physical interactions in the world ocean. Kluwer Academic Publishers, Boston, MA, p 513-526

Tabata S (1982) The anticyclonic, baroclinic eddy off Sitka, Alaska, in the northeast Pacific Ocean. J Phys Oceanogr 12:1260-1282

Tremblay Y, Shaffer SA, Fowler SL, Kuhn CE and others (2006) Interpolation of animal tracking data in a fluid environment. J Exp Biol 209:128-140

Tremblay Y, Roberts AJ, Costa DP (2007) Fractal landscape method: an alternative approach to measuring arearestricted searching behavior. J Exp Biol 210:935-945

Webb PM, Crocker DE, Blackwell SB, Costa DP, Le Boeuf BJ (1998) Effects of buoyancy on the diving behavior of northern elephant seals. J Exp Biol 201:2349-2358

Editorial responsibility: Steven Bograd,

Pacific Grove, California, USA
Weimerskirch H, Doncaster CP, Cuenotchaillet F (1994) Pelagic seabirds and the marine environment-foraging patterns of wandering albatrosses in relation to prey availability and distribution. Proc R Soc Lond 255:91-97

Weimerskirch H, Pinaud D, Pawlowski F, Bost CA (2007) Does prey capture induce area-restricted search? A fine-scale study using GPS in a marine predator, the wandering albatross. Am Nat 170:734-743

> Weng KC, Foley DG, Ganong JE, Perle C, Shillinger GL, Block BA (2008) Migration of an upper trophic level predator, the salmon shark Lamna ditropis, between distant ecoregions. Mar Ecol Prog Ser 372:253-264

Whitney F, Robert M (2002) Structure of Haida eddies and their transport of nutrient from coastal margins into the NE Pacific Ocean. J Oceanogr 58:715-723

Submitted: May 1, 2009; Accepted: November 15, 2009 Proofs received from author(s): January 25, 2010 